\title{
EFFECT OF STIRRUP CORROSION ON THE SHEAR STRENGTH OF REINFORCED CONCRETE SHORT BEAMS
}

\author{
Ahmed K. EL-SAYED, Raja R. HUSSAIN, Ahmed B. SHURAIM \\ Center of Excellence for Concrete Research and Testing, King Saud University, Riyadh, \\ Kingdom of Saudi Arabia
}

Received 26 Mar 2013; accepted 03 Jun 2013

\begin{abstract}
The effect of stirrups damage due to corrosion on the shear strength and behaviour of reinforced concrete beams was experimentally investigated. A total of fourteen full-scale reinforced concrete beams were constructed and tested under four-point bending up to failure. The test beams were $200 \mathrm{~mm}$ wide, $350 \mathrm{~mm}$ deep, and $2800 \mathrm{~mm}$ long. The reinforcing stirrups of nine of the beams were subjected to accelerated corrosion prior to structural testing. The test variables were the corrosion damage level, spacing of stirrups, and shear span to depth ratio. The beams were tested under shear span to depth ratio of 2 or 1 representing short or deep members. The test results indicated that the corroded beams exhibited degradation in stiffness and shear strength in comparison to the uncorroded control specimens. This degradation appeared to increase as the corrosion level increases and as stirrup spacing as well as shear span to depth ratio decreases.
\end{abstract}

Keywords: reinforced concrete, corrosion, short beams, shear strength, stirrups, degradation.

\section{Introduction}

The long-term durability of reinforced concrete structures has become a major concern in the construction industry. The durability of concrete structures depends on the resistance of the concrete against chemical and physical factors and its ability to protect the embedded reinforcement against corrosion. Corrosion of embedded reinforcing steel is one of the main causes of deterioration of reinforced concrete structures. Chloride contamination is the most significant contributor to corrosion of reinforcing steel and many sources of chloride exist. The most common are wind-born salts in coastal areas and roadway deicing agents in colder regions (Higgins, Farrow 2006).

The corrosion process is electro-chemical phenomenon and specific corrosion reactions will depend on the relative amounts of water and oxygen (Bentur et al. 1997). The basic problem associated with the deterioration of reinforced concrete structures due to corrosion is not only that the reinforcing steel itself is reduced in mechanical strength, but also the products of corrosion (rust) which have a volume that can be six times that of steel it replaces (Mehta, Monteiro 1993) creating large tensile stresses within the concrete that can lead to cracking, separation of the concrete cover at the level of reinforcement (delamination) and spalling in which pieces of concrete break loose. This damage results in a reduction in service life and ultimate capacity of the reinforced concrete structure.

There has been considerable research on the effects of corrosion on the flexural strength of beams and the bond strength between the reinforcing steel and the surrounding concrete. The behavior of reinforced concrete beams with corroded steel in the longitudinal direction indicated that both load carrying capacity and ductility were decreased (Oyado et al. 2011; Chung et al. 2008; Azad et al. 2007; Du et al. 2007; Ballim, Reid 2003; Yoon et al. 2000; Mangat, Elgarf 1999; Almusallam et al. 1996; Cabrera 1996). Bond tests indicated loss of bond between concrete and steel with increasing section loss of steel bars due to corrosion (Lee et al. 2002; Auyeung et al. 2000; Amleh, Mirza 1999; Stanish et al. 1999; Al-Sulaimani et al. 1990). On the other hand, there has been limited research on the corrosion effects on the shear behavior of reinforced concrete beams. Higgins and Farrow (2006) conducted an experimental investigation on the corrosion of stirrups and its effect on the shear capacity of reinforced concrete beams. Three different corrosion damage levels were produced through accelerated corrosion technique. The test outcomes indicated that corrosion damaged specimens experienced reduced shear strength and reduced ductility. The test results also indicated that structural performance in shear was affected significantly when

Corresponding author: Ahmed K. El-Sayed

E-mail: ahelsayed@ksu.edu.sa 
sequential stirrups had a reduction in cross sectional area. Suffern et al. (2010) studied the shear strength and behavior of disturbed regions with corroded stirrups in reinforced concrete beams. The beams included embedded stirrups subjected to accelerated corrosion. The test results indicated that the corroded beams exhibited reduced shear strength in comparison to the uncorroded beams.

Shear failures in reinforced concrete members are sudden and catastrophic in nature and should be avoided in the design process. That is why reinforced concrete members are first dimensioned in flexure and then verified for shear. Corrosion of steel stirrups may affect the shear capacity of concrete members and result in undesirable premature shear failures.

\section{Research significance}

Because of their location as an outer reinforcement, stirrups are more susceptible to corrosion and may be subjected to related deterioration, which reduces the service life of the structure. Nevertheless, previous studies on the effects of corrosion on shear reinforcement are limited. The research described in this paper is intended to explore the performance of reinforced concrete short beams with corroded stirrups. The study focuses on accelerated corrosion damage to stirrups within reinforced concrete beams, visual distress characterization, structural behaviour and residual shear strength. These data will be useful for preliminary analysis required for designing efficient repair systems for such damaged beams.

\section{Experimental investigation}

The experimental program consisted of shear tests on a total of 14 full-scale reinforced concrete beams. Nine beams were subjected to accelerated corrosion and the remaining five beams were not corroded. All beams were provided with adequate longitudinal reinforcement to promote shear failure before reaching the flexural capacities of the beams. The test variables included the level of corrosion damage of the steel stirrups, the stirrup spacing, and the shear span to depth ratio.

\subsection{Details of test beams}

The test specimens were $200 \mathrm{~mm}$ wide, $350 \mathrm{~mm}$ deep, and $2800 \mathrm{~mm}$ long. All beams were reinforced with four $25 \mathrm{~mm}$-diameter deformed steel bars as main tensile reinforcement and two $10 \mathrm{~mm}$-diameter deformed steel bars as top reinforcement. The tensile bars were anchored in the test span using a standard hook to prevent anchorage failure. The steel stirrups were deformed bars having a diameter of $8 \mathrm{~mm}$. The side concrete cover of the stirrups was $20 \mathrm{~mm}$. One of the shear spans of the beams was allowed to include corroded stirrups while the other shear span included uncorroded stirrups. The stirrup spacing in the test span was variable $(100,150$, and $200 \mathrm{~mm})$ whereas the spacing of stirrups in the uncorroded span was kept constant at $100 \mathrm{~mm}$ for all beams. The test matrix is given in Table 1 and the reinforcement details and dimensions are shown in Figure 1. The beams were divided into two main groups according to the shear span to depth ratio, a/d. The a/d ratios considered were 1 and 2 to reflect the short or deep beam action. According to ACI 318-11 code (ACI 318 2011), deep beams are defined as members loaded on one face and supported on the opposite face, so that compression struts can develop between load points and supports. Moreover, deep beams have either: a) $\ln / \mathrm{h} \leq 4$; or b) $\mathrm{a} / \mathrm{h} \leq 2.0$ where $\ln$ is the clear span of the deep beam, $h$ is the overall depth, and a is the shear span length. Table 1 shows that 8 beams were tested under a/d ratio of 2 and 6 beams were tested under a/d ratio of 1 . Each group of beams had beams with corroded stirrups and beams with uncorroded stirrups to serve as controls. The corroded beams included

Table 1. Details of test beams

\begin{tabular}{|c|c|c|c|}
\hline Beam & $\begin{array}{l}\text { Shear span to } \\
\text { depth ratio, a/d }\end{array}$ & $\begin{array}{c}\text { Stirrup } \\
\text { spacing } \\
(\mathrm{mm})\end{array}$ & $\begin{array}{c}\text { Target mass } \\
\text { loss }(\%)\end{array}$ \\
\hline $0-200-2$ & \multirow{8}{*}{2} & \multirow{3}{*}{200} & 0 \\
\hline $10-200-2$ & & & 10 \\
\hline $30-200-2$ & & & 30 \\
\hline $0-150-2$ & & \multirow{3}{*}{150} & 0 \\
\hline $10-150-2$ & & & 10 \\
\hline $30-150-2$ & & & 30 \\
\hline $0-100-2$ & & \multirow{2}{*}{100} & 0 \\
\hline $30-100-2$ & & & 30 \\
\hline $0-150-1$ & \multirow{6}{*}{1} & \multirow{3}{*}{150} & 0 \\
\hline $10-150-1$ & & & 10 \\
\hline $30-150-1$ & & & 30 \\
\hline $0-100-1$ & & \multirow{3}{*}{100} & 0 \\
\hline 10-100-1 & & & 10 \\
\hline $30-100-1$ & & & 30 \\
\hline
\end{tabular}

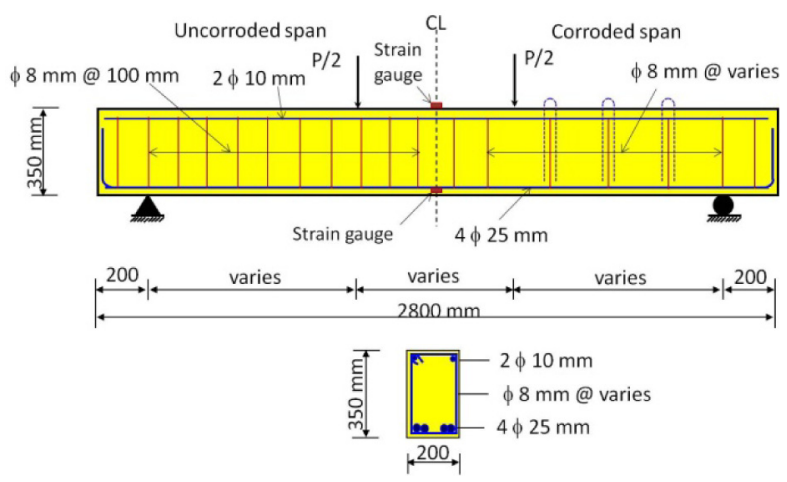

Fig. 1. Typical beam reinforcement and dimensions 
two levels of corrosion damage with target section losses of 10 and $30 \%$. These levels correspond to accelerated corrosion exposure times of 30 days and 120 days, respectively. The designation of the beams uses the first number 0,10 or 30 refers to the target mass loss. The second number 100,150 , or 200 stands for the stirrup spacing. The third number 1 or 2 refers to the shear span to depth ratio.

\subsection{Material properties}

The beams were constructed using concrete provided by a local ready-mix supplier. The concrete was batched at a water-cement ratio of 0.45 and the maximum coarse aggregate size was $20 \mathrm{~mm}$. The 14 beams were cast using two concrete batches. During casting the beams with corrosion stirrups, a measured volume of concrete was removed from the concrete transit mixer truck and salted water was mixed into this concrete in an on-site mixer. The amount of salt added was based on requiring $2 \%$ chlorides by mass of cement. The chloride ions have two purposes: to depassivate the steel so that the corrosion process can occur, and to lower the resistivity of the concrete. The salted concrete was placed only within the region around the corroded stirrups in the test span using dividers. The specimens were wet cured for a period of 7 days, and then allowed to dry cure for a period of at least 21 days. After curing, the accelerated corrosion process was started. The 28-day minimum curing time allowed the concrete to achieve the design strength, so that the corrosion-induced cracking would not be influenced by the time varying concrete strength. For the two concrete batches and at the time of beam testing, the average compressive strengths of the concrete were 29.4 and $38 \mathrm{MPa}$ based on cylinder tests.

Deformed steel bars were used in reinforcing the test beams. Steel bars with diameter of 10 and $25 \mathrm{~mm}$ were used as top and main tensile reinforcement respectively, while steel bars with diameter of $8 \mathrm{~mm}$ were used as stirrups. The yield tensile strength of the reinforcing bars was 495,530 , and $480 \mathrm{MPa}$ for 8,10 , and $25 \mathrm{~mm}$ diameter bars, respectively.

\subsection{Accelerated corrosion of stirrups}

After curing, specimens were subjected to accelerated corrosion. The accelerated corrosion was conducted by impressing a constant current into the concrete beam specimens using an external direct current (DC) power supply. The DC power supply can apply a maximum current of $500 \mathrm{~mA}$ with an accuracy of $1 \%$. The steel stirrups were connected to the positive terminal of the power supply to act as an anode. This occurred through a steel bar welded to the stirrup and extended outside the specimen. A $10 \mathrm{~mm}$ diameter stainless steel tube bent into a $\mathrm{U}$ shape and embedded within the concrete was connected to the negative terminal of the power supply to act as a cathode. The tube was placed around the corroded stirrup, as shown in Figure 1, with an embedment length in the concrete of $300 \mathrm{~mm}$. The ties used to attach the corrosion stirrups were wrapped in electrical tape to prevent an electrical connection with the longitudinal reinforcement. Also, the longitudinal reinforcement was covered with electrical tape at the stirrups location. The longitudinal steel bars were epoxy coated to preclude corrosion of these elements. Figure 2 illustrates the electrical connection of the corroded stirrups. For the purpose of an accelerated corrosion, a current density of $0.4 \mathrm{~mA} / \mathrm{cm}^{2}$ was applied through the stirrups using the DC power supply. Faraday's Law was taken as guidance for determining the amount of time to produce the corrosion damage. A compressed air mist nozzle was used to spray mist over the test specimens to facilitate the corrosion reaction. Figure 3 shows the wiring schematic and Figure 4 illustrates the corrosion setup.

\subsection{Test setup and instrumentation}

After completion of the accelerated corrosion process, the beams were tested up to failure. The beams were tested in four-point bending over a simply-supported clear span of $2400 \mathrm{~mm}$, as shown in Figure 1. Each tested beam was loaded directly on the top compressive face with two concentrated loads according to the considered $\mathrm{a} / \mathrm{d}$ and supported at the bottom. The beams were tested using Amsler Machine with a capacity of $2000 \mathrm{kN}$. Applied load and reactions were transmitted to the tested beams by means of steel plates to prevent premature crushing or bearing failure at these locations. The dimension of the plates at load point locations were $200 \times 110 \times 25 \mathrm{~mm}$ whereas plates of $200 \times 125 \times 25 \mathrm{~mm}$ were used at the support locations. To ensure uniform contact between

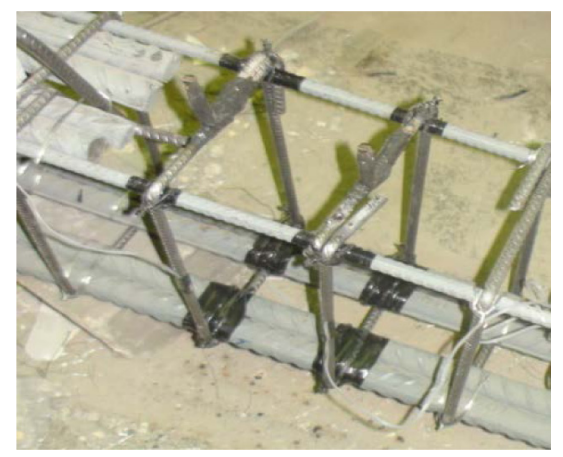

Fig. 2. Stirrup electrical connection

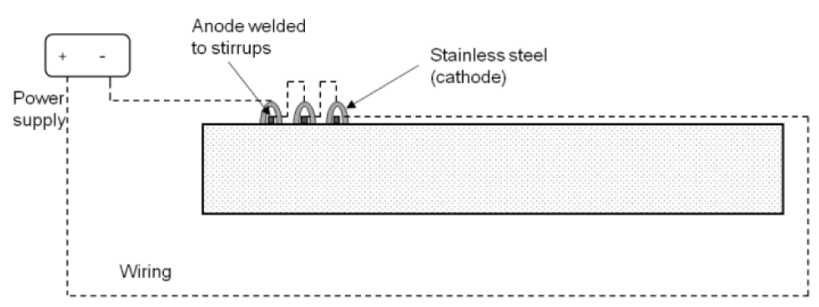

Fig. 3. Schematic of the wiring system 


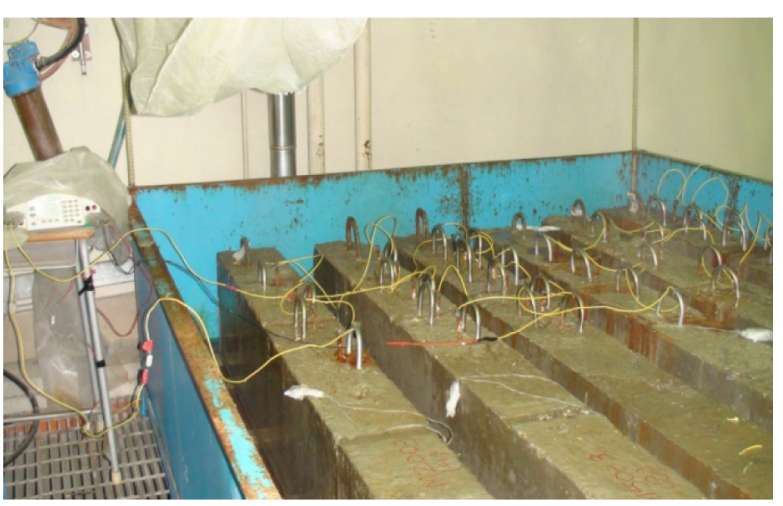

Fig. 4. Accelerated corrosion setup

loading or supporting plates and surface of the specimen, a thin layer of neoprene plate was applied.

Electrical resistance strain gauges of a resistance of $120 \mathrm{ohms}$ were attached to the reinforcement and concrete surface. In each beam, electrical resistance strain gauges were bonded to the longitudinal reinforcing steel and to the top concrete surface at midspan. Additionally, strain gauges were bonded to the steel stirrups at mid height location in the test shear span of the control uncorroded beams. No strain gauges were attached to the stirrups to be corroded as they would be destroyed during the accelerated corrosion phase. The deflection at midspan was measured using two LVDTs at each side of the beam. During testing, load was monotonically applied at a stroke-controlled rate of $1.0 \mathrm{~mm} / \mathrm{min}$ and the formation of the cracks on the sides of the beams were also marked and recorded. The applied load, displacements, and strain readings were electronically recorded during the test using a data acquisition system.

\section{Test results and discussion}

\subsection{Accelerated corrosion results}

During the accelerated corrosion process, all corroded beams showed corrosion cracks and rust staining. The cracks produced from corrosion were traced and recorded. The cracks were primarily vertical at the locations of the vertical stirrups. Secondary longitudinal cracks propagated at or near the location of the longitudinal steel, even though the longitudinal steel was not corroding. A typical corrosion crack pattern is schematically shown in Figure 5.

The crack widths were measured manually using a hand-held 50X microscope with a sensitivity of $0.02 \mathrm{~mm}$. The width of corrosion cracks were measured through a grid of $50 \mathrm{~mm}$ spacing and at the location of clear change in the crack width; with at least 5 measurements per every single crack. The measurements were taken after the accelerated corrosion phase was completed and prior to structural testing. Table 2 summarizes the maximum and average crack width for each beam. It can be noticed that the cracks became wider in beams with higher mass loss. For beams with target mass loss of $10 \%$, the maximum

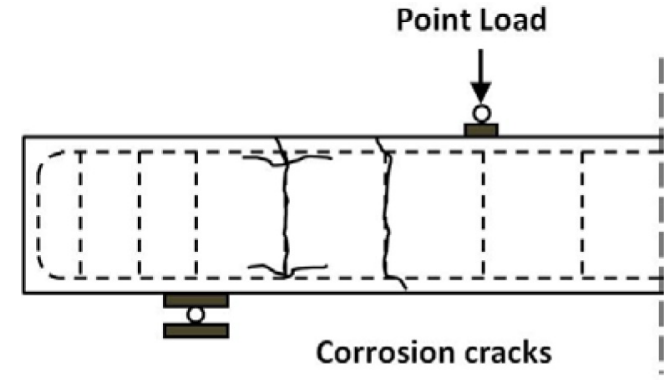

Fig. 5. Typical corrosion crack pattern

Table 2. Corrosion crack width and mass loss.

\begin{tabular}{lccc}
\hline Beam & $\begin{array}{c}\text { Maximum } \\
\text { crack width } \\
(\mathrm{mm})\end{array}$ & $\begin{array}{c}\text { Average } \\
\text { crack width } \\
(\mathrm{mm})\end{array}$ & $\begin{array}{c}\text { Average mass } \\
\text { loss }(\%)\end{array}$ \\
\hline $10-200-2$ & 0.16 & 0.08 & 16.5 \\
\hline $30-200-2$ & 0.42 & 0.30 & 22.2 \\
\hline $10-150-2$ & 0.20 & 0.14 & 12.3 \\
\hline $30-150-2$ & 0.48 & 0.32 & 21.5 \\
\hline $30-100-2$ & 0.52 & 0.38 & 23.6 \\
\hline $10-150-1$ & 0.20 & 0.13 & 15.8 \\
\hline $30-150-1$ & 0.30 & 0.20 & 20.3 \\
\hline $10-100-1$ & 0.22 & 0.18 & 17.8 \\
\hline $30-100-1$ & 0.40 & 0.30 & 24.0 \\
\hline
\end{tabular}

crack width ranged between 0.16 and $0.22 \mathrm{~mm}$ compared to 0.3 and $0.52 \mathrm{~mm}$ for beams with target mass loss of $30 \%$. Similar observation can be noted when the average crack width in Table 2 are compared.

In addition to the visual inspection of corrosion damage and crack width measurements, the actual mass loss of the corroded stirrups was determined based on the procedure specified in ASTM G1-03 (2011). After structural testing, corroded stirrups were removed from the beam to determine the amount of section mass loss. The visual inspection of the corroded stirrups indicated that the corrosion was relatively uniform over each individual stirrup with more localized mass loss at or near the bends in the stirrup. Reinforcing steel coupons that had a length of $200 \mathrm{~mm}$ were extracted from both legs of corroded stirrups for mass loss measurements. The mass loss for each beam was determined based on the average mass loss for the shear reinforcement in the failure region. Table 2 gives the average mass loss for each beam. It can be noted that beams of target mass loss of $10 \%$ showed actual mass loss in the range of 12.3 to $17.8 \%$ while actual mass loss in the range of 21.5 to $24 \%$ was showed for beams of $30 \%$ target mass loss.

The correlation between maximum or average crack width and the actual mass loss of the corroded stirrups is presented in Figure 6. As a general trend, both maximum and average crack width was increased as the actual mass loss increased. This correlation between width of corrosion 


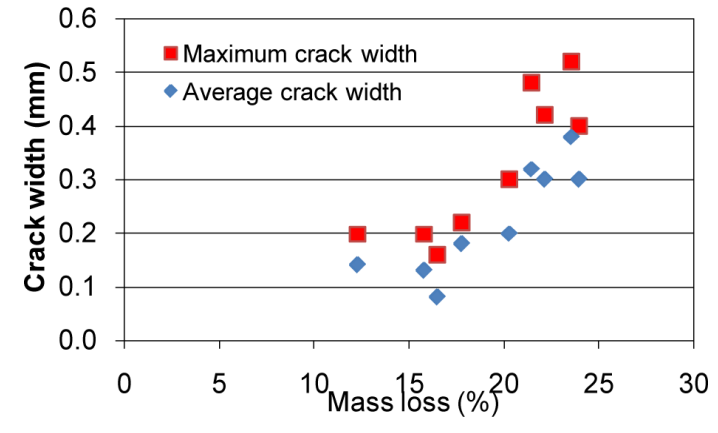

Fig. 6. Correlation between corrosion crack width and mass loss

crack and section mass loss of stirrups reflects the possibility of the corrosion cracks to serve as a measure of the damage extent caused by corrosion. For corrosiondamaged members in real structures, the average mass loss is very difficult to be evaluated while the corrosion crack width can be practically measured.

\subsection{General structural behaviour}

A summary of the beam test results is presented in Table 3 . The table gives the measured load at diagonal cracking and at ultimate, the ultimate strength reduction due to corrosion of stirrups, the mid span deflection and strains, and the failure mode.

The applied load versus midspan deflection plots for beams of a/d ratio of 2 are shown in Figure 7 whereas Figure 8 shows the deflection plots for beams of a/d ratio of 1. Each figure presents the load-deflection response for beams having the same stirrup spacing. The figures indicate that the corroded beams experienced higher deflection than the corresponding control beam at the same load level. The stiffness degradation in the corroded specimens can be attributed to the corrosion cracking and loss of bond between the corroded stirrups and concrete. This result indicates that corrosion of shear reinforcement affects the flexural behaviour of beams by producing higher deflection that may lead to serviceability problems.

In the early stages of loading, flexural cracks were observed in the region of pure bending as the applied load was increased. With a further increase of load, additional flexural cracks were developed in the pure bending zone and new flexural cracks were formed on the shear span between the loading point and support. Diagonal cracks were formed within the shear span after the flexural cracks became apparent. The crack propagation was interrupted by the vertical corrosion cracks, but the diagonal cracks eventually propagated through the corrosion cracks. The flexural cracks had formed earlier then stabilized and stopped propagating.

The failure modes of the fourteen beams are given in the last column of Table 3. No premature failure due to anchorage failure of the tension reinforcement or due to bearing failure at the supports or at the loading points was observed. Three failure modes were obtained: shear-compression failure, rupture of stirrups, and diagonal crushing failure. The shear-compression failure is characterized by crushing of the concrete above the upper end of the inclined crack. Most of the control beams with uncorroded stirrups in addition to beam 30-100-2 with corroded stirrups failed in shear compression. All corroded beams with a/d of 1 and 2 failed by rupture of stirrups except beams of closely spaced stirrups (100 mm spacing). Rupture of stirrups occurred due to the reduction in cross-sectional area of the bars caused by

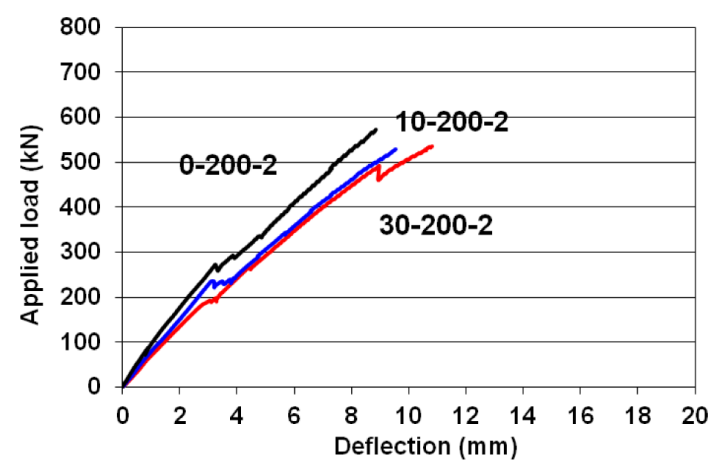

(a) Beams of $200 \mathrm{~mm}$ stirrup spacing

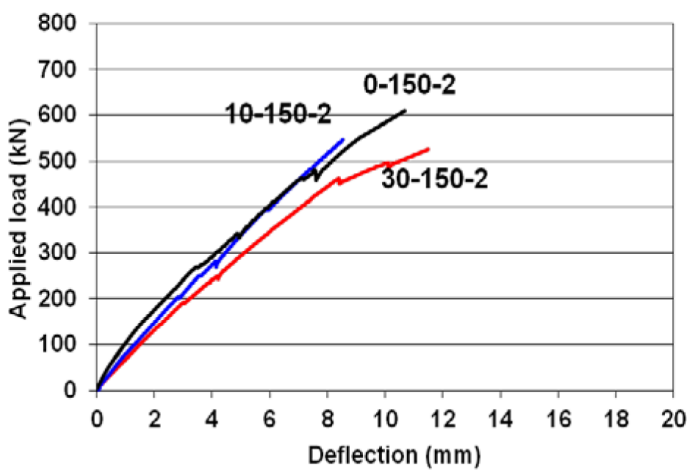

(b) Beams of $150 \mathrm{~mm}$ stirrup spacing

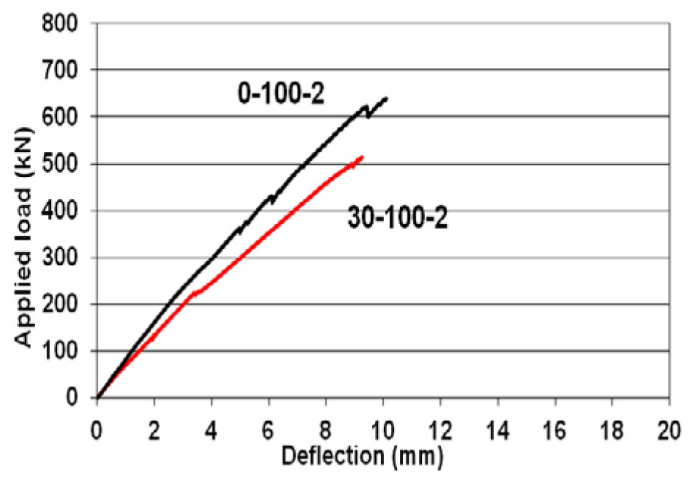

(c) Beams of $100 \mathrm{~mm}$ stirrup spacing

Fig. 7. Load-deflection relationship for beams of $\mathrm{a} / \mathrm{d}=2$ 
Table 3. Summary of test results

\begin{tabular}{|c|c|c|c|c|c|c|c|c|c|c|}
\hline \multirow{2}{*}{ Beam } & \multirow{2}{*}{$\begin{array}{l}\text { Concrete } \\
\text { strengt, } \\
\mathrm{MPa}\end{array}$} & \multicolumn{2}{|c|}{ Measured load (kN) } & \multirow{2}{*}{$\begin{array}{l}\text { Ultimate } \\
\text { strength } \\
\text { reduction } \\
\quad(\%)\end{array}$} & \multirow{2}{*}{$\begin{array}{c}\text { Mid-span } \\
\text { deflection } \\
\text { at failure } \\
\quad(\mathrm{mm})\end{array}$} & \multicolumn{2}{|c|}{$\begin{array}{l}\text { Mid-span strain } \\
(\mu \varepsilon)\end{array}$} & \multirow{2}{*}{$\begin{array}{l}\text { Max. } \\
\text { stirrup } \\
\text { strain } \\
(\mu \varepsilon)\end{array}$} & \multirow{2}{*}{$\begin{array}{c}\text { Average } \\
\text { mass loss } \\
(\%)\end{array}$} & \multirow{2}{*}{$\begin{array}{l}\text { Failure } \\
\text { mode* }\end{array}$} \\
\hline & & $\begin{array}{l}\text { Diagonal } \\
\text { cracking }\end{array}$ & Ultimate & & & $\begin{array}{l}\text { Long. } \\
\text { bars }\end{array}$ & concrete & & & \\
\hline $0-200-2$ & \multirow{8}{*}{38} & 189 & 572 & - & 8.9 & 1777 & -1590 & 3036 & - & $\mathrm{SC}$ \\
\hline $10-200-2$ & & 230 & 529 & 8 & 9.5 & 1685 & -1175 & - & 16.5 & SR \\
\hline $30-200-2$ & & 280 & 535 & 6 & 10.8 & 1757 & -1413 & - & 22.2 & SR \\
\hline $0-150-2$ & & 191 & 610 & - & 10.7 & 1882 & -1475 & 3411 & - & $\mathrm{SC}$ \\
\hline $10-150-2$ & & 260 & 547 & 10 & 8.5 & 1710 & -1245 & - & 12.3 & SR \\
\hline $30-150-2$ & & 285 & 526 & 14 & 11.5 & 1645 & -1228 & - & 21.5 & SR \\
\hline $0-100-2$ & & 202 & 640 & - & 10.1 & 1956 & -1477 & 3829 & - & $\mathrm{SC}$ \\
\hline $30-100-2$ & & 277 & 512 & 20 & 9.2 & 1602 & -1297 & - & 23.6 & $\mathrm{SC}$ \\
\hline $0-150-1$ & \multirow{6}{*}{29.4} & 233 & 1040 & - & 9.0 & 1446 & -1356 & 2960 & - & $\mathrm{SC}$ \\
\hline $10-150-1$ & & 310 & 916 & 12 & 8.2 & 1318 & -1208 & - & 15.8 & SR \\
\hline $30-150-1$ & & 356 & 845 & 19 & 8.2 & 1006 & -1125 & - & 20.3 & SR \\
\hline $0-100-1$ & & 287 & 1105 & - & 10.4 & -+ & -1372 & 2875 & - & $\mathrm{DC}$ \\
\hline $10-100-1$ & & 394 & 892 & 19 & 7.8 & 1162 & -1227 & - & 17.8 & $\mathrm{DC}$ \\
\hline $30-100-1$ & & 421 & 841 & 24 & 8.4 & 1050 & -1089 & - & 24.0 & $\mathrm{DC}$ \\
\hline
\end{tabular}

Note: * DC - diagonal crushing; SC - shear compression; SR - stirrup rupture, + Strain gauge malfunctioned.

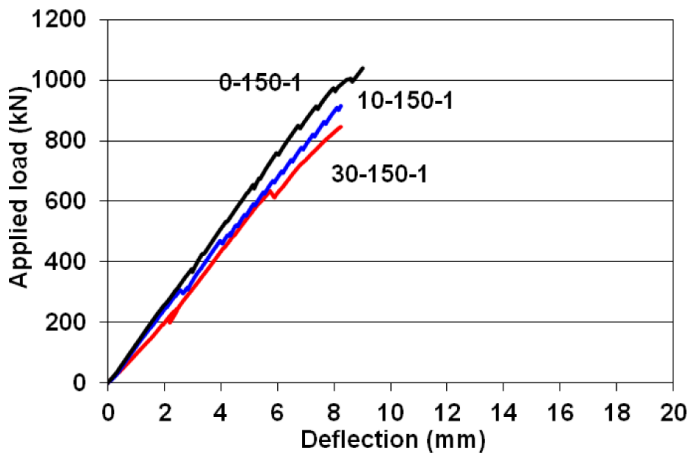

(a) Beams of $150 \mathrm{~mm}$ stirrup spacing

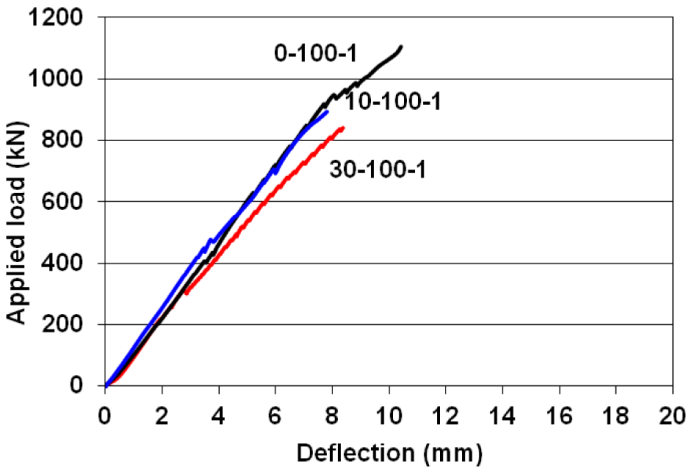

(b) Beams of $100 \mathrm{~mm}$ stirrup spacing

Fig. 8. Load-deflection relationship for beams of $\mathrm{a} / \mathrm{d}=1$

corrosion. The three beams with a/d of 1 and stirrup spacing of $100 \mathrm{~mm}$ failed in crushing of the diagonal strut, as given in Table 3. Figure 9 illustrates by photographs the three modes of failure observed in this investigation.

Table 3 gives the measured midspan strains in the longitudinal reinforcement and concrete at failure for each beam. Also, the maximum stirrup strains are also given in Table 3 for the control uncorroded beams. For all tested beams, the measured concrete compressive strain at failure ranged from 1089 to 1590 micro-strain which is lower than the usable concrete crushing strain of 3000 micro strain. The tensile strain developed in the longitudinal bars at failure varied between 1006 and
1956 micro-strain which is less than the yield strain of 2400 micro-strain of these bars. These results indicate that no flexural failure has occurred either by yielding of the longitudinal steel bars or by concrete crushing. The maximum stirrup strains at failure varied from 2875 to 3829 micro-strain indicating that the stirrups yielded before the complete failure of the beams as the yield strain of stirrups was 2600 micro-strain.

\subsection{Shear strength}

The diagonal cracking load for all specimens is given in Table 3. It can be noted that the corroded beams showed increased diagonal cracking load compared to the 


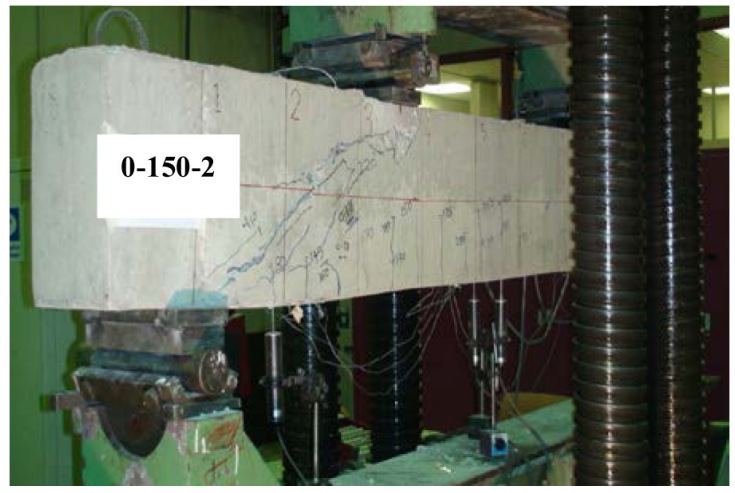

(a) Shear compression failure (0-150-2)
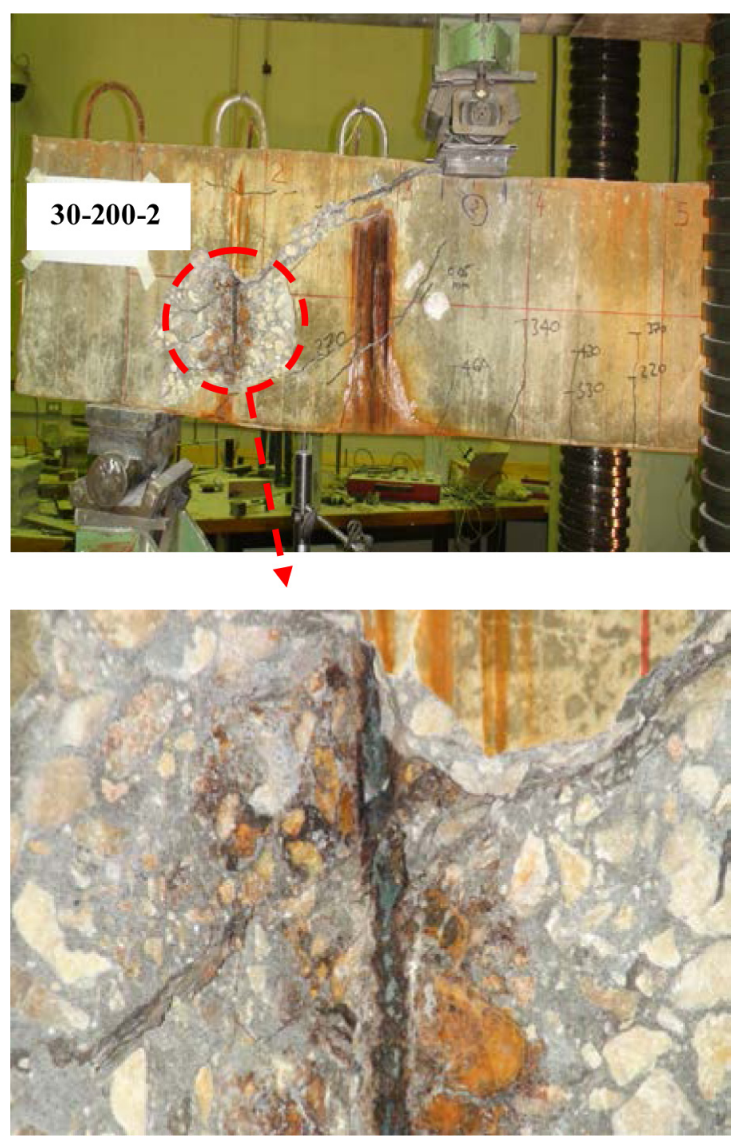

(b) Stirrup rupture failure (30-200-2)

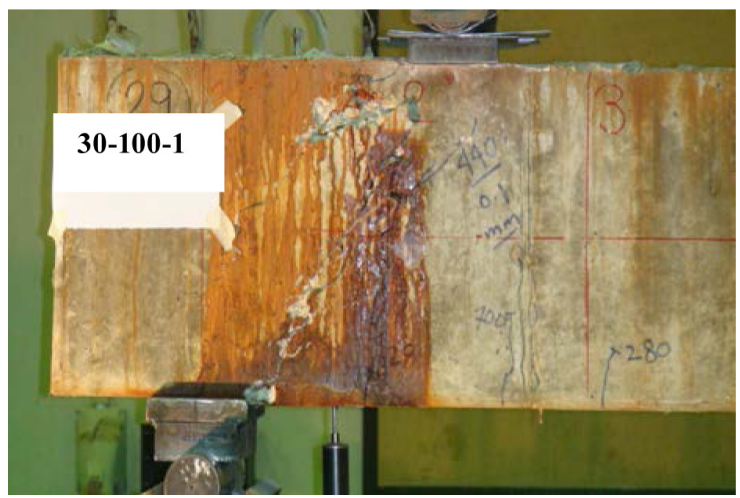

(c) Diagonal crushing failure (30-100-1)

Fig. 9. Failure modes uncorroded beams. Further, the diagonal cracking load appeared to increase with the degree of corrosion. Beams of $30 \%$ target mass loss experienced higher diagonal cracking load than that of $10 \%$ target mass loss beams. This observation was also reported by other investigators (Higgins, Farrow 2006; Suffern et al. 2010). It is likely due to the corrosion cracks, different load paths were developed in the corroded beams delaying the onset of diagonal cracks and resulting in higher shear cracking load.

The corroded beams showed degradation in ultimate shear strength when compared with that of uncorroded control beams. Table 3 provides a measure of this degradation in terms of the reduction in shear capacity of the corroded beams. The reduction in shear capacity of the corroded beams ranged from 6 to $24 \%$ depending on the test variables considered. It is well known that the main role of the reinforcing stirrups in short or deep members is to control diagonal cracking as most of the load is transferred directly to the support through concrete struts that connect the concentrated load and the support. The concrete damage due corrosion including cracking and delamination of concrete cover makes these struts less efficient in transferring the load to the supports. In addition, the efficiency of the stirrups in restraining the diagonal crack is reduced because of the reduced area of the damaged stirrups. All these effects resulted from corrosion contributed to reduce the overall shear capacity of the beams with corroded stirrups.

The variation of the reduction in shear capacity was plotted against the degree of corrosion in terms of average mass loss, average corrosion crack width, and maximum corrosion crack width as presented in Figures 10 through 12, respectively. Figure 10 indicates that the shear strength reduction was proportional to the average mass loss of the reinforcing bars; this was more pronounced for the beams of a/d ratio of 1 . Figures 11 and 12 clearly indicate that the reduction in shear capacity increased with the increase of both average and maximum corrosion crack width. This observation points out that the corrosion crack width could be employed as an indicator of the residual shear capacity of reinforced concrete beams with corroded stirrups.

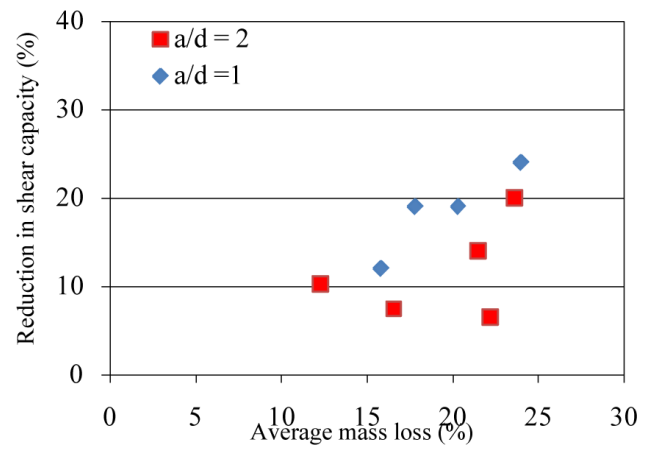

Fig. 10. Variation of reduction in shear capacity with average mass loss 


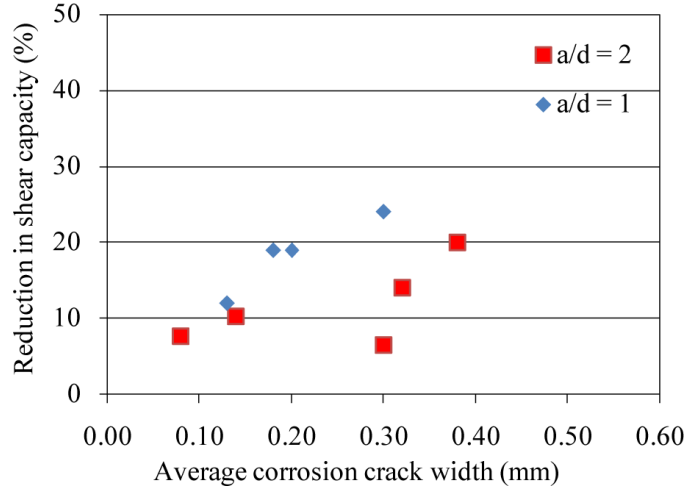

Fig. 11. Variation of reduction in shear capacity with average corrosion crack width

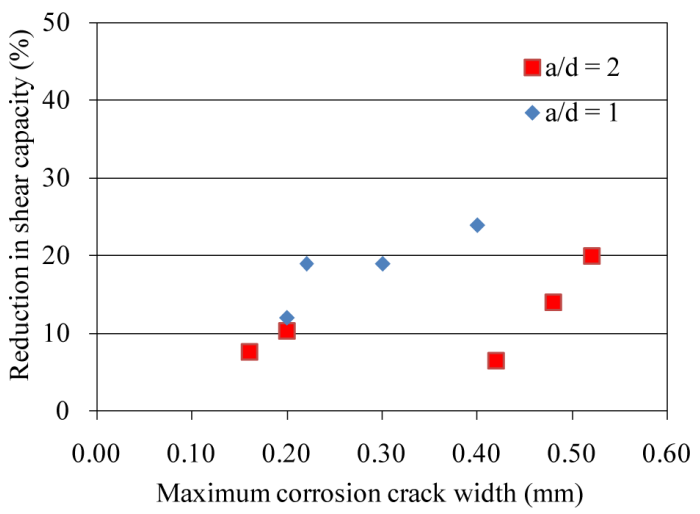

Fig. 12. Variation of reduction in shear capacity with maximum corrosion crack width

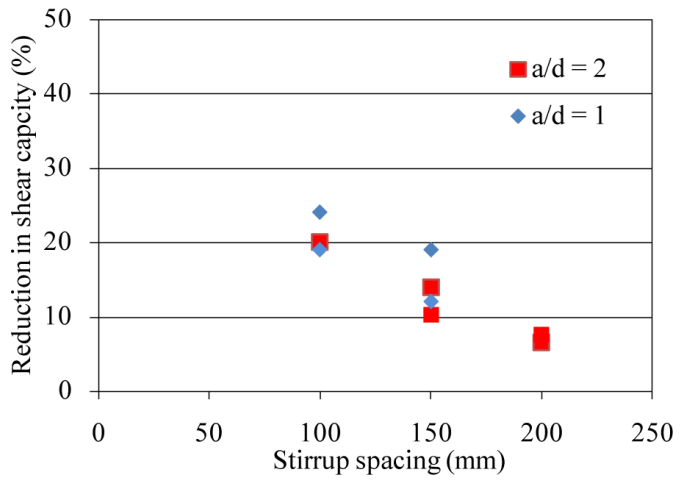

Fig. 13. Variation of reduction in shear capacity with stirrup spacing

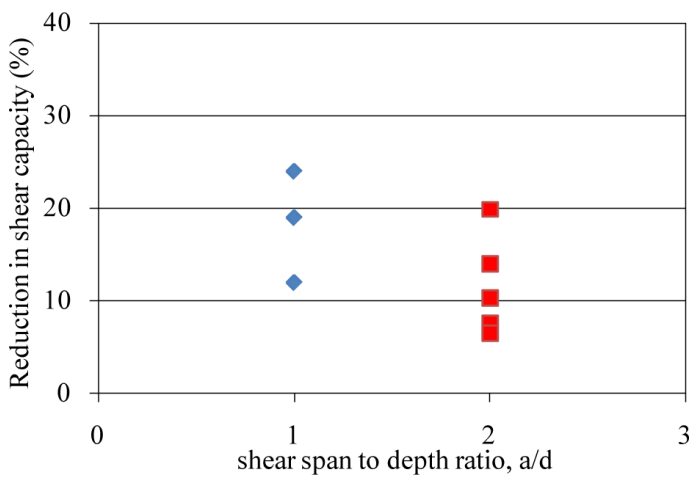

Fig. 14. Variation of reduction in shear capacity with shear span to depth ratio
The effect of the stirrup spacing on the reduction in shear capacity is presented in Figure 13. The reduction in shear strength became larger for beams with closely spaced stirrups. This result may be expected because more corrosion cracks were developed in such beams in comparison with beams of wider stirrup spacing. The reduction in shear strength was plotted against a/d ratio in Figure 14. The general trend indicates that the reduction in shear capacity increases with the decrease of a/d ratio.

\section{Conclusions}

The effect of stirrup corrosion on the shear strength and behaviour of reinforced concrete short beams was investigated in this study. The main findings of this investigation can be summarized as follows:

- Visual inspection of the beams after completion of the accelerated corrosion process showed evidence of corrosion cracking and stains in all specimens. The corrosion crack width appeared to be a measure of the corrosion level of the corroded stirrups. The crack width became wider with the increase of corrosion level of stirrups.

- All corroded beams showed degradation and reduction in stiffness and shear strength compared to uncorroded beams. This degradation increased as the corrosion level was increased.

- Unlike the control beams, all corroded beams failed by rupture of stirrups due to corrosion except the beams with closely spaced stirrups.

- The reduction in shear strength due to corrosion of stirrups appeared to increase with the decrease in stirrup spacing as well as with the decrease in the shear span to depth ratio while it appeared to increase with the increase of corrosion crack width.

\section{Acknowledgements}

This work was supported by NSTIP strategic technologies programs, number (10-BUI1191-02) in the Kingdom of Saudi Arabia. The help of engineers and technicians in the Centre of Excellence for Concrete Research \& Testing (CoE-CRT) and in the structural laboratory of Civil Engineering Department at King Saud University is highly appreciated.

\section{References}

ACI Committee 318. 2011. Building code requirements for structural concrete and commentary, ACI 318-11/ACI 318R-11. American Concrete Institute, Farmington Hills, MI. 503 p.

Almusallam, A. A.; Al-Gahtani, A. S.; Aziz, A. R.; Dakhil, F. H.; Rasheeduzzafar. 1996. Effect of reinforcement corrosion on flexural behaviour of concrete slabs, Journal of Materials in Civil Engineering 8(3): 123-127.

http://dx.doi.org/10.1061/(ASCE)0899-1561(1996)8:3(123)

Al-Sulaimani, G. J.; Kaleemullah, M.; Basunbul, I. A.; Rasheeduzzafar. 1990. Influence of corrosion and cracking on bond behaviour and strength of reinforced concrete members, ACI Structural Journal 87(2): 220-231. 
Amleh, L.; Mirza, S. 1999. Corrosion influence on bond between steel and concrete, ACI Structural Journal 96(3): 415-423.

ASTM G1-03. Evaluating corrosion test specimens. ASTM International, West Conshohocken, Pa.

Auyeung, Y.; Balaguru, P.; Chung, L. 2000. Bond behaviour of corroded reinforcement bars, ACI Materials Journal 97(2): 214-220.

Azad, A. K.; Ahmad, E. F.; Azher, S. A. 2007. Residual strength of corrosion-damaged reinforced concrete beams, $A C I$ Structural Journal 104(1): 40-47.

Ballim, Y.; Reid, J. C. 2003. Reinforcement corrosion and the deflection of RC beams - an experimental critique of current test methods, Journal of Cement and Concrete Composites 25(6): 625-632. http://dx.doi.org/10.1016/S0958-9465(02)00076-8

Bentur, A.; Diamond, S.; Berke, N. S. 1997. Steel corrosion in concrete. New York: E\&FN Spon. 201 p.

Cabrera, J. G. 1996. Deterioration of concrete due to reinforcement steel corrosion, Journal of Cement and Concrete Composites 18(1): 47-59. http://dx.doi.org/10.1016/0958-9465(95)00043-7

Chung, L.; Najm, H.; Balaguru, P. 2008. Flexural behaviour of concrete slabs with corroded bars, Journal of Cement and Concrete Composites 30(8): 184-193. http://dx.doi.org/10.1016/j.cemconcomp.2007.08.005

Du, Y.; Clark, L. A.; Chan, A. H. 2007. Impact of reinforcement corrosion on ductile behavior of reinforced concrete beams, ACI Structural Journal 104(3): 285-293.
Higgins, C.; Farrow, W. C. 2006. Tests of reinforced concrete beams with corrosion damaged stirrups, ACI Structural Journal 103(1): 133-141.

Lee, H. S.; Noguchi, T.; Tomosawa, F. 2002. Evaluation of the bond properties between concrete and reinforcement as a function of the degree of reinforcement corrosion, Cement and Concrete Research 32(8): 1313-1318. http://dx.doi.org/10.1016/S0008-8846(02)00783-4

Mangat, P. S.; Elgarf, M. S. 1999. Flexural strength of concrete beams with corroding reinforcement, ACI Structural Journal 96(1): 149-158.

Mehta, P.; Monteiro, J. 1993. Concrete, structure properties, and materials. $2^{\text {nd }}$ ed. Englewood Cliff: Prentice-Hall. $160-164$.

Oyado, M.; Kanakubo, T.; Sato, T.; Yamamoto, Y. 2011. Bending performance of reinforced concrete member deteriorated by corrosion, Journal of Structure and Infrastructure Engineering: Maintenance, Management, Life-Cycle Design and Performance 7(1-2): 121-130

Stanish, K.; Hooton, R. D.; Pantazopoulou, S. J. 1999. Corrosion effects on bond strength in reinforced concrete, $A C I$ Structural Journal 96(6): 915-921.

Suffern, C.; El-Sayed, A. K.; Soudki, K. 2010. Shear strength of disturbed regions with corroded stirrups in reinforced concrete beams, Canadian Journal of Civil Engineering 37(8): 1045-1056. http://dx.doi.org/10.1139/L10-031

Yoon, S.; Wang, K.; Weiss, W. J.; Shah, S. P. 2000. Interaction between loading, corrosion, and serviceability of reinforced concrete, ACI Material Journal 97(6): 637-644.

\begin{abstract}
Ahmed K. EL-SAYED. He is an Associate Professor in the Centre of Excellence for Concrete Research and Testing at King Saud University, Riyadh, Saudi Arabia. He received his PhD from the University of Sherbrooke, Sherbrooke, QC, Canada. His research interests include corrosion, rehabilitation and reinforcing of concrete structures using FRP composites. He is an associate professor (on leave) in the Housing and Building National Research Center, Giza, Egypt.
\end{abstract}

Raja R. HUSSAIN. He is an Associate Professor in the Centre of Excellence for Concrete Research and Testing at King Saud University, Riyadh, Saudi Arabia. He received his MS and PhD in Civil Engineering from the University of Tokyo, Japan. He has authored more than 150 publications and has received several awards, prizes and distinctions throughout his research and academic career.

Ahmed B. SHURAIM. He is a Professor in the Department of Civil Engineering at King Saud University, Riyadh, Saudi Arabia. He received his BS from King Saud University and his MS and PhD from the University of Michigan, Ann Arbor, MI. His research interests include the behavior of reinforced concrete structures through testing and nonlinear finite element modeling. 